\title{
Impact of Dividend Policy on Shareholders' Wealth: An Empirical Analysis of Listed Insurance Companies in Pakistan
}

\author{
MUHAMMAD SHABEER KHAN \\ MS Scholar, Department of Management Sciences \\ University of Swabi, K.P.K, Pakistan \\ Shabeerkhan902@gmail.com \\ DR. SAID SHAH \\ Assistant professor, Department of Management Sciences \\ University of Swabi, K.P.K, Pakistan \\ SYEDA UROOJ BABER \\ Lecturer, Department of Management Sciences \\ University of Swabi, K.P.K, Pakistan
}

\begin{abstract}
This study aims to investigate the impact of dividend policy on shareholders' wealth using secondary data of 17 listed insurance companies in Pakistan employing nonprobability convenience sampling for 2012-2015. Shareholders' wealth is used as dependent variable measured by earning per share whereas dividend policy as independent variable measured by three ratios namely dividend per share, Retention ratio and dividend payout ratio. Analysis techniques include descriptive statistics, regression analysis and correlation analysis. The results show that all the independent variables impact dependent variable positively with dividend per share and retention ratio significant at 5\%. Moreover study reveals that the theory of dividend irrelevancy failed in the case of insurance industry of Pakistan.
\end{abstract}

Keywords: Dividend policy, Shareholders wealth, Earnings per share, Dividend payout, Retention and Dividend per share

\section{Introduction}

Dividend policy has distinctive value in corporate world for the purpose to achieve organizational objectives efficiently. According to Moyer (2001, p.19) "Dividend policy determines the final distribution of the companies' earnings between retention and cash dividend payments of shareholders". The retained earnings give financiers with a wellspring of possible upcoming earning development, while dividend provides them a present circulation. There is some common and basic dividend policies are mention such as regular dividend policy, stable or constant dividend policy, no dividend policy and the last one is irregular dividend policy. The issue has great importance in corporate world that whether the firm earnings should be invested back in future favorable project or should be distributed among stockholders. For solving this issue financial manager extremely concentrated to find out that dividend policy which is more suitable to increase 
stockholders wealth as well as result in growth of corporation. Most of the shareholders prefer cash dividend but at the same time they are also interested in the corporation growth for capital appreciation which lead management to reinvest the firm earnings in productive projects.

The financial managers are working as agent of owners' in corporations, so the first priority and objective of financial managers in organization to maximize wealth of stockholders which demonstrate by the share market value. Dividend policy focus on two decision functions, either to pay earnings as dividend or to reinvest in firm future projects. Any change in dividend policy may have positively or negatively effects on firm stock price. Higher payout ratio lead to higher quick cash flow to investors, which is good, but higher payout also lead to lower future growth, which is bad for corporation and also for investors in long term. The optimal dividend policy maintains balance between these difference and increase market price of share which represents maximization of shareholders wealth.

\subsection{Problem Statement}

Under financial management in corporate sector dividend policy has high preference. There are different views about, how dividend policy affects shareholders wealth. According to one view (Linter 1956; Fama 1969, p.19), the dividend policy has positive relationship with the stockholders' wealth, whereas another view (Miller \& Modigliani 1961; Fischer \& Scholes 1974, p.19/20) argued that shareholders' wealth is not influenced through dividend policy. So this review concentrates impact on stockholders' wealth by dividend policy.

\subsection{Objectives of the Study}

The study has the following two main objectives:

- To discover the link of dividend policy with shareholders' wealth in Pakistan listed insurance industry.

- To scrutinize the influence on shareholders wealth by dividend policy in Pakistan listed insurance industry.

\subsection{GDP Comparison with Different Countries' Insurance Sectors}

At the end of 2014, the insurance industry of china contributed $2.98 \%$, Germany $8.57 \%$, India $3.86 \%$, Turkey $1.45 \%$, USA $14.1 \%$, and Indonesia $1.85 \%$ while the insurance industry of Pakistan contributed $0.80 \%$ in GDP (Express Tribune 2015).

\section{Literature Review}

Scrutinizing the influence on stockholders' wealth by dividend policy, using earnings per share as dependent and return on equity, dividend Payout ratio and dividend per share as independent variables and based on 12 non-financial companies, and employing correlation and regression as analysis technique, Balagobei (2015, p.18) found a positive and significant relationship between dependent and independent variables. Likewise there was also a robust impact represented of dividend per share toward shareholders' wealth through regression analysis. The study also suggested that dividend policy had created valuable and robust impact on shareholders' wealth as such there be a suitable and strong dividend policy for promoting shareholders' wealth and motivating investors toward organization. Linter (1956, p.19) found positive relationship of dividend policy with stockholders' wealth and suggested dividend payment reduced investor uncertainty and also increase share value. 
Ansar, et al. (2015, p.18) analyzed the relationship of dividend policy with stockholders' wealth in Pakistani market. Study used 30 firms as a sample from such sectors, textile, chemical and cement. The market price per share was used as dependent variable while return on equity, retained earnings per share, lagged price, dividend per share were used as independent variables and employee Multiple regression model for analysis. The finding indicated positive and robust relationship of dividend policy with stockholders' wealth. Gul et al., (2012, p.19) studied the association between dividend policy and stockholders' wealth. The study used multiple regression and stepwise regression models which showed highly significant impact of dividend policy on shareholders' wealth.

The investigated work intended to find out the influences on shareholders' wealth from dividend policy. With the help of quota random sampling tool, 10 listed companies were chosen, out of 216 companies from different sectors during period of 2015. Data was collected through questionnaires and ANOVA was applied for analyzing the data. After analysis of various theories of dividend policy the finding showed that dividend policy influenced the shareholders' values in Nigeria, because investor preferred to present dividend on future retention policy and capital appreciation. Further the findings indicated that higher market share value depends upon higher dividend payment ratio and vice versa (Ozuomba et al., 2016, p.19). The research study conducted by Amidu and Abor (2006, p.18) for the purpose to discover the determining factors of dividend payout ratio, with using Twenty firms as a sample during 1998-2003. It was found that dividend payout policy has positive relationship with profitability, corporate tax and cash flow, while other side dividend payout has negative relationship with sale growth, institutional holding, market to book value and risk.

Pani (2008, p.19) tried to find out the association of stock price behavior with dividend policy of the firm. The Sample contained six different firms of Bombay Stock Exchange from interval of 1996 to 2006. It was found through fixed effect model that there was positive relationship of retention ratio with stock return. Ilaboya \& Aggreh (2013, p.19) investigated the influence on stock price volatility by dividend policy. The study used 30 companies as a sample from Nigerian stock exchange during period of 2005 to 2011. Finding presented long term debt, dividend yield and asset growth positive and significant influence on share price volatility. Khan $(2012$, p.19) studied the relationship of dividend announcement with share price. Fixed and Random effect model were used in study. Thirty listed companies were chosen as a sample during 2001-2010. Finding indicated positive significant association of share market value with profit after tax, stock dividend and earnings per share. Long Lee, et al (2012, p.19) studied the effect of intra industry cash dividend announcement for real estate investment trust of U.S. The research study covered during 2001 to 2008 and used Short window event methodology. The finding showed contagion effects of real estate investment trust dividend announcement. Further contagion effect found higher in case of dividend decreasing event.

The study conducted to assess the association of dividend payment with ownership structure in China Stock Exchange during 1997 to 1999; it was found that government control firms interested to pay more dividend as compare to corporate control companies. Further that multiple large shareholders' corporations paid less dividend than without multiple large shareholders firms. Besides that there was positive relationship of dividend payout with ownership of the controlling stockholders (Zhao, 2012, p.20). Miller and 
Modigliani (1961, p.19) found, the share price and firms capital cost had not affected by dividend policy and gave arguments that firm value only depend on earning power of the firm and its assets risk. The Company added more risk by increasing the amount of debt in case of paying dividend to stock holders.

Rahman and Nazim-ud-Din (2014, p.20) studied the relationship of dividend with share price volatility and found negative insignificant impact of dividend announcement on stock price volatility in the context of Bangladesh marketplace. Study conducted by Tahir and Sarfaraz raja $(2014$, p.18) to scrutinize the impact on shareholders wealth by dividend policy. Holding period yield was used as dependent variable and dividend payout, price to earnings ratio, and BV/MV equity ratio were used as independent variables. Through Convenience Sampling six companies were chosen as a sample from oil and gas sector of Pakistan Stock Exchange. The dependent variable showed insignificant link with independent variables.

The purpose of conducted research review to discover the relationship of dividend policy with shareholders' wealth. Finding showed highly significant influence of dividend per share on market price per share as compare to retained earnings per share (Rehman 2015, p.19).Intention of research review to studied the determining factor of dividend policy in emerging market. The dividend payout ratio was used dependent variable and for measuring independent variables used ratios namely agency cost, firm size, profitability, Leverage ratio and growth. The 680 firms were used as a sample out of 978 firms from Bursa Malaysia Stock Exchange during 2005 to 2009. There was significant relationship found between dividend payout ratio and firm size, leverage and profitability (Mahdzan et al., 2016, p.19).

Azhagaiah and Pria (2008, p.18) analyzed the link of dividend policy with stockholders' wealth. The research review used 28 chemical companies as a sample during 19972006.It was found significant impact on shareholders' wealth by dividend policy. Amidu (2007, p.18) tried to discover the impact of dividend policy on companies performance and found that, dividend policy influence firm's performance. The Return on equity and growth in sale positively influenced from dividend policy, while dividend payout indicate negative relationship with return on asset and leverage.

Maharshi and Malik (2015, p.19) tried to know the influence of dividend policy on market value of shares and growths of Joint Stock Companies. The market price of share was used as dependent variable and for measuring independent variable used four ratios; namely dividend yield, retention ratio, Profit after tax and earning per share. The study used 30 listed companies as a sample during 2011-2012. The outcome demonstrated that share price volatility and dividend yield had strong relationship and also positively associated, while other side share price volatility and assets growth indicated highly negative relationship. The Study conducted for the purpose to estimate the association of dividend policy with share price during 2007 to 2009. The finding demonstrated that price earnings ratio and earnings per share were significant positive impact on stock price and dividend yield revealed negative relationship with share price (NTUI Ponsian et al., 2015, p.19).

The Purpose of conducted research review to discover the influence on share price by dividend payment. In study Cal bank, Eco bank and Anglo Gold were randomly chosen out of 36 firms from Ghana Stock Exchange during 2005 to 2009. The finding revealed 
that dividend payment positively affected on share price. Moreover dividend payment was a components behind the increased of share demand in Ghana Stock Exchange (Attah-Botchwey, 2014, p.19). Akif Shah and Noreen (2016, p.20) tried to assess the link between dividend policy and stock price volatility, based on 50 dividend paying companies out of 11 industries. They used stock price volatility dependent variable and dividend payout and dividend yield as independent variables. The verdict indicated dividend yield and dividend payout negative significant influenced on share price volatility.

Iqbal, et al (2014, p.19) studied the influence on share price by dividend. The study used dependent variable market value of share and for measuring independent variable used ratios namely; profitability, dividend payout, price earnings, earnings per share, return on equity, retention ratio and dividend yield. The study chosen 30 companies as a sample and employee multiple ordinary least square model. The research indicated dividend yield and price earnings negative significant impact on market value of stock price, while all other variables showed positive significant influence on market value of share. Alim et al., (2014, p.18) studied the impact on stockholders' wealth by dividend policy during 2001-2010, found that dividend policy positive and significant influenced on shareholders' wealth in the Pakistan textile industry.

\subsection{Conceptual Framework}

Conceptual Framework in figure 1 indicates the main theme of current research work.

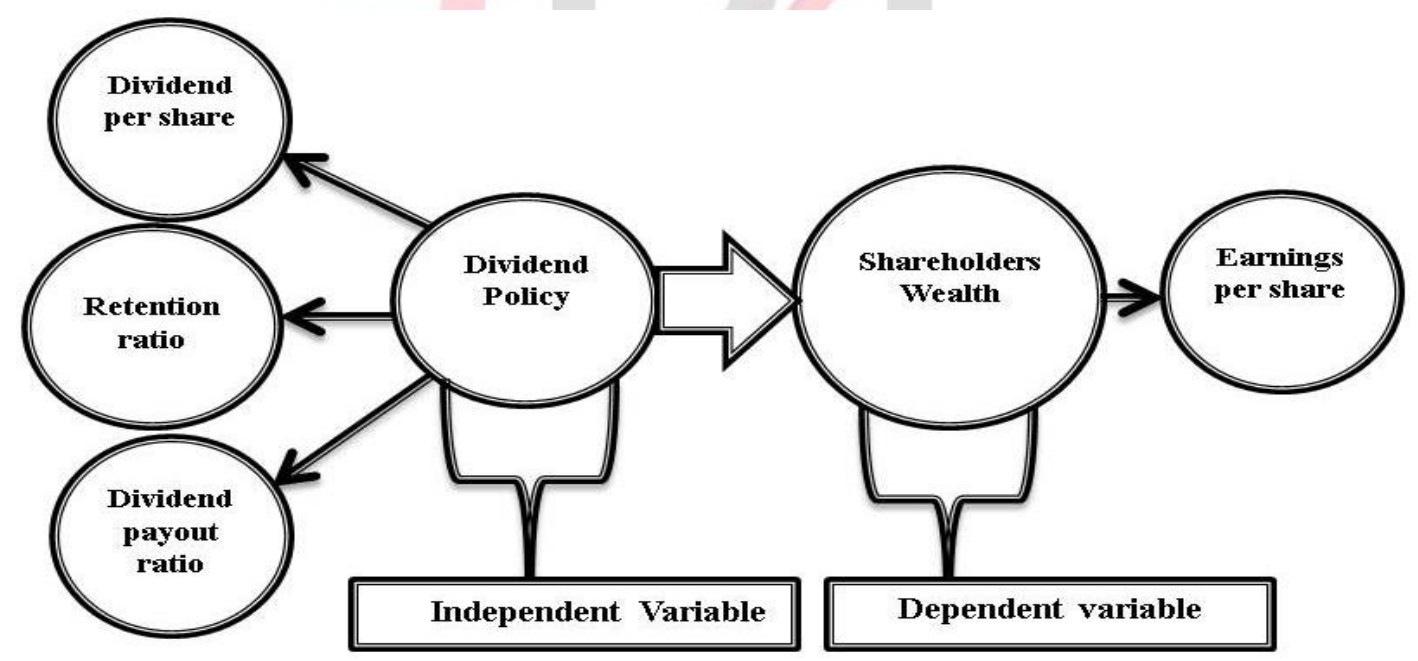

\subsection{Hypotheses}

Keeping in view the above; this study tests the following hypotheses.

$H^{l}$ : The impact of dividend per share on earnings per share is positive and significant in Pakistani insurance sector.

$H^{2}$ : The influence of retention ratio on earnings per share is positive and significant in Pakistani insurance industry.

$H^{3}$ : The influence of dividend payout ratio on earnings per share is positive and significant in Pakistani insurance industry. 


\section{Methodology}

\subsection{Research Design}

The study uses the quantitative casual correlational research design and employed panel study in longitudinal research for the purpose of data analysis.

\subsection{Data Collection}

This study uses secondary data collected from Pakistan stock exchange and official websites of sample companies. The study collect data about variables form the audited annual reports and financial statements of companies.

\subsection{Target Population}

The target population of research is insurance companies listed on Pakistan Stock Exchange for the period 2012-2015.

\subsection{Sampling}

The Pakistan stock exchange has 35 sectors representing 578 companies in 2016. The insurance sector of Pakistan stock exchange has total 32 companies, which is net population of present research study. In this population 17 companies are choses through convenience sampling during 2012 to 2015 which shown in table1.

Table 1: Sample companies of present study

\begin{tabular}{|c|c|c|c|c|c|}
\hline No & Listed insurance companies names & No & Listed insur & ance compani & es names \\
\hline $\mathbf{1}$ & $\begin{array}{l}\text { Pakistan } \\
\text { Limited }\end{array}$ & 10 & Atlas Insurar & ce Limited & \\
\hline 2 & $\begin{array}{l}\text { The United Insurance Company of } \\
\text { Pak Ltd }\end{array}$ & 11 & $\begin{array}{l}\text { East West } \\
\text { Limited }\end{array}$ & Insurance & Company \\
\hline 3 & Cyan Limited & 12 & $\begin{array}{l}\text { Adamjee } \\
\text { Limited }\end{array}$ & Insurance & Company \\
\hline 4 & $\begin{array}{l}\text { Jubilee General Insurance Company } \\
\text { Ltd }\end{array}$ & 13 & \multicolumn{3}{|c|}{ IGI Insurance Limited } \\
\hline 5 & EFU General Insurance Limited & 14 & IGI life Insur & ance Limited & \\
\hline 6 & Habib Insurance Company Limited & 15 & $\begin{array}{l}\text { Askari Gene } \\
\text { Ltd }\end{array}$ & ral Insurance & Company \\
\hline 7 & Century Insurance Company Limited & 16 & Asia Insuran & Company L & imited \\
\hline 8 & $\begin{array}{l}\text { Pakistan General Insurance Company } \\
\text { Ltd }\end{array}$ & 17 & Silver Star In & surance Co. L & imited \\
\hline 9 & Reliance Insurance & & & & \\
\hline
\end{tabular}

3.5. Econometric Model of present study

$\mathrm{EPS}=\alpha+\beta 1 \mathrm{DPS}+\beta 2 \mathrm{DPR}+\beta 3 \mathrm{RR}+\mathrm{u}$

Whereas: $\alpha$ : is the $\mathrm{y}-$ intercept; $\mathrm{u}$ mean regression residual and $\beta$ represent the slop of coefficient.

\subsection{Measuring techniques of study}

Table 2 shows variables and their measurement for current study.

Table 2: show variables and their measurement for current study.

\begin{tabular}{llllll}
\hline No & $\begin{array}{l}\text { Variable types } \\
\text { Dependent variable }\end{array}$ & $\begin{array}{l}\text { Variable } \\
\text { Earnings } \\
\text { share }\end{array}$ & per & $\begin{array}{l}\text { Measurement } \\
\text { Net profit after tax/No. } \\
\text { of ordinary share }\end{array}$ & $\begin{array}{l}\text { Abbreviations } \\
\text { EPS }\end{array}$ \\
\hline $\mathbf{1}$ & $\begin{array}{l}\text { Independent } \\
\text { Variables }\end{array}$ & $\begin{array}{l}\text { Dividend } \\
\text { share }\end{array}$ & per & $\begin{array}{l}\text { Dividend/ No. of } \\
\text { ordinary share }\end{array}$ & DPS \\
\hline
\end{tabular}




\begin{tabular}{llll}
\hline 2 & Dividend & yearly dividend per & DPR \\
payout ratio & share/earning per share \\
Retention ratio & $\begin{array}{l}\text { Net income-dividend/net } \\
\text { income }\end{array}$ & RR \\
\hline
\end{tabular}

4. Data Analysis and Findings

4.1 Descriptive Analysis

Table 3: Represents the result of descriptive statistics

\begin{tabular}{|c|c|c|c|c|c|}
\hline 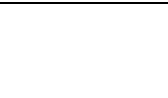 & $\mathbf{N}$ & Minimum & Maximum & Mean & $\begin{array}{l}\text { Standard. } \\
\text { Deviation }\end{array}$ \\
\hline EPS & 17 & 1.21 & 16.36 & 5.7601 & 4.52430 \\
\hline DPS & 17 & 0.25 & 5.88 & 2.4920 & 1.80378 \\
\hline DPR & 17 & 0.16 & 3.46 & 0.6132 & 0.75847 \\
\hline $\mathbf{R R}$ & 17 & 0.18 & 0.84 & 0.5666 & 0.18258 \\
\hline $\begin{array}{r}\text { Valid N } \\
\text { (listwise) }\end{array}$ & 17 & & & & \\
\hline
\end{tabular}

The above table 3 represents the result of descriptive statistics in which the values of earnings per share have 1.21 of minimum and 16.7601 of maximum rupees with 5.7601 mean and 4.52430 of Standard deviation. Likewise each study variable shows their minimum, maximum, mean and standard deviation value in various study years.

\subsection{Correlation analysis}

\begin{tabular}{|c|c|c|c|c|}
\hline & EPS & DPS & DPR & $\mathbf{R R}$ \\
\hline EPS $\quad$ Pearson Correlation & 1 & $.821 * *$ & -.070 & -.099 \\
\hline Sig. (2-tailed) & & .000 & .788 & .704 \\
\hline $\mathbf{N}$ & 17 & 17 & 17 & 17 \\
\hline
\end{tabular}

**. Correlation is significant at the 0.01 level (2-tailed).

*. Correlation is significant at the 0.05 level (2-tailed).

The above table four shows positive significant correlation between EPS and DPS, besides that dividend payout and retention have negative insignificant correlation with earning per share. 


\subsection{Regression Analysis}

Table 5: show result of regression coefficient

\begin{tabular}{|c|c|c|c|c|c|c|c|}
\hline \multirow[t]{2}{*}{ Variables } & \multirow[t]{2}{*}{ coefficient } & \multirow[t]{2}{*}{$\begin{array}{c}\text { Std. } \\
\text { Error }\end{array}$} & \multirow[t]{2}{*}{ Beta } & \multirow[t]{2}{*}{ t-statistics } & \multirow[t]{2}{*}{$\begin{array}{c}\mathbf{P} \\
\text { value }\end{array}$} & \multicolumn{2}{|c|}{$\begin{array}{c}\text { Collinearity } \\
\text { Statistics }\end{array}$} \\
\hline & & & & & & Tolerance & VIF \\
\hline $\mathrm{C}$ & -8.353 & 2.910 & & -2.870 & 0.013 & & \\
\hline DPS & 2.742 & 0.331 & 1.093 & 8.273 & 0.000 & 0.684 & 1.462 \\
\hline DPR & 0.208 & 0.752 & .035 & 0.276 & 0.787 & 0.752 & 1.330 \\
\hline $\mathbf{R R}$ & 12.624 & 3.687 & 0.509 & 3.424 & 0.005 & 0.539 & 1.855 \\
\hline
\end{tabular}

Dependent Variable: EPS

In above table 5 , the coefficient of DPS indicates positive significant impact on dependent variable because P value for DPS is less than (<.05), that means if 1 unit change occurs in dividend per share then 2.742 unit variations bring in earning per share. Likewise coefficient of RR also indicates positive significant impact on dependent variable because $\mathrm{P}$ value for $\mathrm{RR}$ is also less than $(<.05)$, which means 1 unit change in retention ratio brings 12.624 unit variation in earning per share, while DPR indicates insignificant impact on dependent variable. Beside that VIF test shows that, there is no multicollinearity problem.

\subsection{Model Summary and ANOVA}

Table 6: show the result of Model Summary and ANOVA

\begin{tabular}{llllll}
\hline R-squared & $\begin{array}{l}\text { Adjusted } \\
\text { squared }\end{array}$ & $\begin{array}{l}\text { R- } \\
\text { Wurbin- } \\
\text { Watson }\end{array}$ & F-statistics & Sig \\
\hline 0.845 & 0.809 & 12.375 & 23.586 & 0.000 \\
\hline
\end{tabular}

The above table 6 shows that R2 of the model is 0.84 , which denotes that $84 \%$ of the aggregate variance in dependent factor is caused through the change of all the independent variables, thus shows the overall powerful strength of the model. Moreover, value of the adjusted $\mathrm{R}^{2}$ is 0.809 , which states that $80 \%$ of variation described by independent variables in dependent variable, and also the Durbin-Watson show no autocorrelation issue. Besides that The regression model in ANOVA table has good fitted the data because the F- statistics in econometric model is significant at one percent level of significance, which demonstrating that overall regression model is statistically significant predicted the dependent variable, $\mathrm{F}(3,13)=23.586, \mathrm{P}<.0005$.

\subsection{Hypotheses testing summary}

Table 7: Represents Hypotheses testing summary

\begin{tabular}{llll}
\hline No & Hypotheses & Methods & Outcome \\
$\mathbf{H}_{1}$ & $\begin{array}{l}\text { The impact of dividend per share on earnings per share } \\
\text { is positive and significant in Pakistani insurance sector. }\end{array}$ & $\begin{array}{l}\text { Regression } \\
\text { Analysis }\end{array}$ & Accepted \\
$\mathbf{H}_{2}$ & $\begin{array}{l}\text { The influence of retention ratio on earnings per share is } \\
\text { positive and significant in Pakistani insurance industry. }\end{array}$ & $\begin{array}{l}\text { Regression } \\
\text { Analysis }\end{array}$ & Accepted \\
\end{tabular}




\begin{tabular}{llll}
\hline $\mathbf{H}_{3}$ & $\begin{array}{l}\text { The influence of dividend payout ratio on earnings per } \\
\text { share is positive and significant in Pakistani insurance } \\
\text { industry. }\end{array}$ & $\begin{array}{l}\text { Regression } \\
\text { Analysis }\end{array}$ & Rejected \\
\hline
\end{tabular}

In above table $7, \mathrm{H}_{1}$ and $\mathrm{H}_{2}$ hypotheses are accepted because the regression test shows positive significant impact of dividend per share and retention on shareholders' wealth. Besides that the $\mathrm{H}_{3}$ hypothesis is rejected due to insignificant impact found of dividend payout on earnings per share.

\section{Discussion}

Influence of dividend policy on shareholders' wealth has been discussed through different researchers in various countries, but still it's a big issue for financial managers and also for board of directors in corporate sector. The basic aim of financial managers in corporation to maximize shareholders' wealth, and for this purpose they try to find out the best indicator through which investors attract toward them organization and also beneficial for their organization in short and long term. Therefore the finding of current study recommends that the dividends per share and retention ratio are best indicators for financial manager in maximizing shareholders' wealth. Because the retention ratio and dividend per share both have positive and significant impact on shareholders' wealth, it means that the investors in Pakistan insurance industry consider dividend per share as a quick source of profit for themselves, as well they are interested in organization growth because they also prefer capital appreciation with cash dividend. So the finding indicates that organization needs to formulate that type dividend policy in which they handle consistently both elements of dividend policy such as dividend and retained earnings, it will help for attracting investors toward organization, maximization shareholders' wealth and beneficial for long term growth of organization.

\subsection{Conclusion}

The current study has been completed which started under the intent, to find out the influences on shareholders' wealth by dividend policy in Pakistan insurance industry. The research achieves two main objectives, the impact and relationship of dividend policy with shareholders' wealth. The correlation test demonstrates significant positive link of earnings per share with dividend per share, while the regression analysis also represents positive significant impacts on earning per share by dividend per share. The finding of dividend per share is supported previous works like as Azhagaiah \& priya (2008) Ansar et al, (2015) and Balagobei (2015). In the remaining two ratios the retention ratio has positive significant impact on earnings per share which is also supported the previous study of Ansar et al, (2015), and dividend payout ratio has positive insignificant impact on shareholders' wealth and also negative insignificant correlated with shareholders' wealth which is supported the study of Tahir and Sarfaraz raja (2014) and NTUI Ponsian, et al (2015). Furthermore the finding indicates that the theory of dividend irrelevancy failed in the case of insurance industry of Pakistan stock exchange. Base on finding the corporation need to formulate such dividend policy which give equal preference to dividend and retained earnings in organization because the investors of Pakistan insurance industry prefer dividend as well as they are interested in capital gain.

\subsection{Implications of Study}

The findings of study is especially beneficial for financiers, directors, senior managers, policy makers and research students. The retention ratio and dividend per share are 
different in nature with each other. But the outcome of current research show positive and significant relationship of retention ratio and also dividend per share with shareholders' wealth, which simple mean investors prefer current profit as well as interested in capital appreciation. Therefore it's essential for corporations to formulate that kind dividend policy which meet the existing and also upcoming expectation of the financiers. Further, study contributes theoretically and empirically knowledge for academicians through finding the influence on shareholders' wealth by dividend policy in Pakistani insurance sector. Thus, it will provide worthwhile help to academicians in future research in Pakistan as well as any abroad country.

\subsection{Limitations of study}

Generalization: The findings of current study are limited to only insurance industry so therefore the result may not be generalized to all Pakistan stock exchange listed companies.

Time Constraint: The span of the research is not sufficient to pay in-depth attention the different financial aspects of the insurance companies

Period of Analysis: The time of four financial years utilize for the investigation are not ample to finish up about all the perspective.

Wide Area to Study: This study has wide range but could not be cover entirely due to the shortage of time and resources.

Secondary Data: The data utilizes for the analysis are secondary in nature which has taken from the annual reports of the Sample Companies.

\subsection{On the basis of the findings of the study, we recommend future research as under}

The upcoming research is suggested to extend the range of current study in the country as well as extended study to other country. This comparative study will be worthwhile especially for multinational corporations in the world by knowing the behavior of dividend policy with shareholders' wealth in different nation's financial or manufacturing sectors.

\section{References}

Ansar, I., Butt, A. A., \& Shah, S. B. (2015). Impact of Dividend Policy on Shareholder's Wealth. International Review of Management and Business Research, 4(1), 8995.

Amidu, M., \& Abor, J. (2006). Determinants of dividend payout ratios in Ghana. The Journal of Risk Finance, 7(2), 136-145.

Asma, T. \& Raja, N. (2014). Impact of Dividend Policy on Shareholder Wealth. IOSR Journal of Business and Management, 16(1), 24-33.

Alim, W., Ali, A., Ali, N., Khattak, B. K., \& Qureshi, M. I. (2014). Impact of dividend policy on shareholders wealth in pakistan(Evidence textile industry perspective). Gomal University Journal of Research, 30(1), 18-31.

Azhagaiah, R., \& .N, S. P. (2008). The Impact of Dividend Policy on Shareholders' Wealth. International Research Journal of Finance and Economics, 180-187.

Amidu, M. (2007). How does dividend policy affect performance of the firm on Ghana Stock Exchange. Investment Management and Financial Innovations, 4(2),103-111. 
Balagobei, M. S. (2015). Dividend Policy and Shareholders' Wealth of Listed Manufacturing Companies in Sri Lanka. Journal of Economics and Sustainable Development, 6(19), 33-38.

Botchwey, E. A. (2014). The Impact of Dividend Payment on Share Price of Some Selected Listed Companies on the Ghana Stock Exchange. International Journal of Humanities and Social Science, 4(9), 179-190.

Fam a, E. F., Fisher, L., C, M., Jensen, \& Roll, R. (1969). The adjustment of stock prices to new information. International Economics Review, 10(1), 1-21.

Gul, S., Sajid, M., Razzaq, N., Iqbal, M. F., \& Khan, M. B. (2012). “The Relationship between Dividend Policy and Shareholder's Wealth"(Evidence from Pakistan). Economics and Finance Review, 2(2), 55 - 59.

Iqbal, A., Ahmed, F., \& Shafi, A. R. (2014). The Effect of Dividend Bubble on Share Price: Evidence from KSE-30 Index. Research Journal of Finance and Accounting, 5(13), 83-87.

Ilaboya, O. J., \& Aggreh, M. (2013). Dividend Policy and Share Price Volatility. Journal of Asian development studies, 2(2), 109-122.

Khan, K. I. (2012). Effect of Dividends on Stock Prices- A Case of Chemical and Pharmaceutical Industry of Pakistan. Scientific \& Academic Publishing, 2(5), 141-148.

Lintner, J. (1956). Distribution of Incomes of Corporations Among Dividens, Retained Earnings, and Taxes. The American Economic Review, 46(2), 97-113.

Lee, M.-L., Lin, C.-W., Chiang, K. C., \& Kuo, S.-H. (2012). The Intra-Industry Effects of REIT Dividend. Pacific Rim Property Research Journal, 18(1), 35-48.

Moyer Mc Guigan Kretlow, Contemporary Financial Management, Eight edition, Southwestern College Publishing, 2001 p. 516

Miller, M. H., \& Modigliani, F. (1961). Dividend Policy, Growth, and the Valuation of Shares. The Journal of Business, 34(4), 411-433.

Maharshi, D., \& Malik, S. (2015). The Impact Of The Dividend Policy On The Market Price Of The Shares And Growth Of Joint Stock Companies Covered In Sensex. International Journal of Innovative Science, Engineering \& Technology, 2(1), 169-178.

Mahdzana, N. S., Zainudina, R., \& Shahri, N. K. (2016). Interindustry dividend policy determinants in the context of an emerging market. Economics research Ekonomska Istrazivanja, 29(1), 250-262.

Ozuomba, C., Anichebe, A., \& Okoye, P. (2016). The effect of dividend policies on wealth maximization - a study of some selected plcs. Cogent Business \& Management, 1-15.

Pani, U. (2008). Dividend Policy and Stock Price Behaviour in Indian Corporate Sector:A panel data approach. Retrieved From India Institude of Technology, $1-29$.

Ponsian, N., Prosper, K., Yuda, T., \& Samwel, G. (2015). Relationship, between, Dividend, Policy and Share Price. Archives of Business Research, 3(3), 11-20.

Rehman, M. W. (2015). Impact of Dividend Policy on Stockholders' Wealth: Empirical Evidences from KSE 100-Index. International knowledge sharing platform, 5(15), 124-129. 
Rahman, M. M., \& Nazim-ud-Din, M. (2014). Impact of Dividends on Stock Price Volatility:Evidence from Some Selected listed Companies in Bangladesh. Abasyn Journal of Social Sciences, 7(1), 47-56

Shah, S. A., \& Noreen, U. (2016). Stock Price Volatility and Role of Dividend Policy: Empirical Evidence from Pakistan. International Journal of Economics and Financial Issues, 6(2), 461-472.

Scholes, F. B. (1974). The effect of dividend yield and dividend policy on common stock price and return. Journal of Financial Economics, 1, 1-22.

Zhao, Y. (2012). Dividend payment and ownership structure in the Chinese stock market. Asia- Pacific Journal of Accounting \& Economics, 7 (2000), 129-141

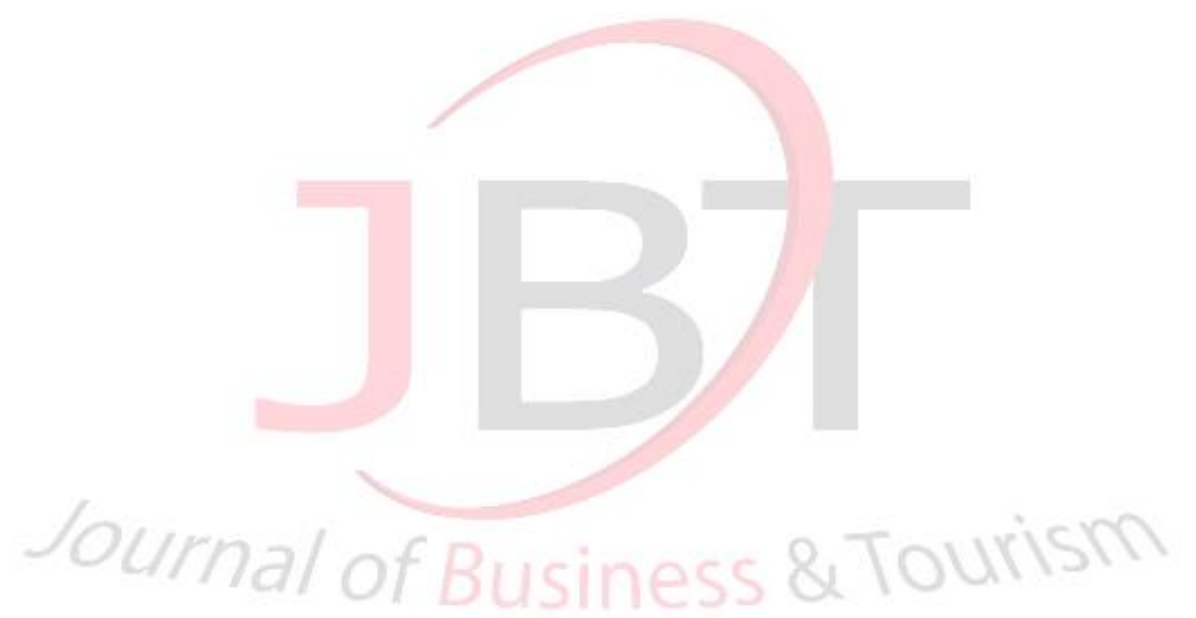

